\title{
ENERGY CONSUMPTION AND OVERLOADS OF CRANE HOISTING MECHANISM WITH SYSTEM OF REDUCING OPERATIONAL LOADS
}

\author{
ENERGOCHŁONNOŚĆ I PRZECIĄŻALNOŚĆ MECHANIZMU PODNOSZENIA \\ SUWNICY Z UKŁADEM ZMNIEJSZANIA OBCIĄŻEŃ EKSPLOATACYJNYCH*
}

\begin{abstract}
The paper presents the study of the hoisting mechanism for various lifting cases. For the developed method of reducing an operating overloads of the driving system of the hoisting mechanisms, studies of the energy consumption of the cycle and the dynamic overloads of the drive (and bearing structure) have been conducted in comparison with other methods of the payload lifting. The influence of a start-up time on the overloads and energy overloads of the mechanism was determined, taking into account the whole duty cycle time. Using the proposed start-up time, the influence of a lifting height and a weight of the lifted load on the drive overload and duty cycle power consumption were shown. Studies have shown good operating properties of a drive with overloads compensation system.
\end{abstract}

Keywords: hoisting winch, overloads, energy consumption, energetic efficiency.

\begin{abstract}
W artykule przedstawiono badania mechanizmu podnoszenia dla różnych przypadków podnoszenia ładunku. Dla opracowanej metody zmniejszania przeciązeń eksploatacyjnych układu napędowego mechanizmów podnoszenia przeprowadzono badania porównawcze energochtonności cyklu roboczego i przeciążalności dynamicznej napędów (i konstrukcji nośnej) w stosunku do innych sposobów rozruchu. Określony został wpływ czasu rozruchu na przeciązalność i przeciażalność energetyczna mechanizmu z uwzględnieniem czasu całego cyklu roboczego. Przedstawiono badania wptywu wysokości podnoszenia i masy podnoszonego tadunku na przeciążalność mechanizmu i energochtonność cyklu roboczego. Badania wykazaty dobre własności eksploatacyjne napędu wykorzystującego metody kompensacji przeciążén.
\end{abstract}

Słowa kluczowe: wciagarka, przeciążenia, energochłonność, efektywność energetyczna.

\section{Introduction}

The energy consumption of production processes is more often considered in the context of possible energy savings. The important role during a process of goods making is played by different kinds of transportation devices including gantries. Those devices, equipped with at least three mechanisms, have different characteristics of their work. A winch is the most energy consumable mechanism. The possibilities of energy recuperation (during a payload lowering) or consumption minimization are also most significant in this mechanism. Issues of energy consumption of hoisting mechanisms are currently being considered in the context of energy saving, reduction of steel construction loads (also design guidelines) or possibilities of energy storage.

The authors of [4] describing energy efficiency of goods making processes, underlined the relevant impact of transport operations as one of auxiliary processes in automated production cycles. They assumed that their simplified method of energy consumption assessment could serve as a tool for analyzing different strategies of controlling the transport devices to perform transport operations with minimal energy consumption.

A lot of researchers treat hosting mechanisms as ,generators” of steel structures loading and vibrations which impacts on deformation of crane structures. As the example might serve [3] where authors pointed that the hybrid approach of finite element method and system dynamics simulation of the overhead traveling crane in the case of lifting a payload allowed to define dynamic loads of crane structure already during designing phase. Similarly in [1] there was presented the model of a crane used to estimate the dynamic coefficient of structure load caused by lifting operation. The authors had also pointed, that future research should consider an influence of hoisting mechanism on dynamic overloads. In [15], the authors underlined the inevitability of considering an energy consumption during the cranes designing. They focus mainly on the structural aspects of the device using the load probability distribution of the hoisting mechanism. The minimization of overloads and vertical oscillations of crane steel structure caused by a hoisting mechanism operation using control systems with PID regulator were presented in [5].

Research on optimization of crane structure using energy efficiency in regard to dynamic coefficients of a payload lifting was presented in [18]. The effects of research were the reduction of the device mass, what caused less power consumption during horizontal movements.

A lot of research teams were concentrated on crane mechanisms in context of payload trajectory and sway minimisation using proper input function. It was confirmed inter alia in [13], where authors pointed the systems counteracting payload swaying and bridge bevelling as main direction of research and development of control systems of cranes movements.

(*) Tekst artykułu w polskiej wersji językowej dostępny w elektronicznym wydaniu kwartalnika na stronie www.ein.org.pl 
Some teams conducted a research of energetic efficiency of motors which were used in hoisting mechanisms fed by inverters. The research presented in [12] showed, that increasing the energetic effectiveness of motors did not make tangible benefits. It was caused by short times of operation and a large share of partial load of the mechanism.

In [2] the necessity of energy saving in lifting devices was pointed. The authors state that energy saving was possible in two manners, energy recuperation during payload lowering and increasing speed (for small masses of lifting payloads). The method of determining the energy consumption by using the calculation of changes of potential energy during lifting operation and the work of horizontal movements was presented in [16]. The method of energy saving using flywheel was also presented. The problems of energy efficiency evaluation of overhead crane using neural nets were presented in [17]. The another method of storage, which was connected with increasing development of supercapacitors was presented inter alia in [10] and [11]. Supercapacitors began to be used as storages of energy recuperated during payloads lowering or braking of cranes.

The research of energetic effectiveness of transport devices exploitation was conducted on many ways, however during lifting phase some savings are possible in methods of payload acceleration. The savings of these area gave huge (in respect with travelling mechanisms) energetic effects, both in the form of minimisation of power consumption and minimisation of dynamic overloads in drive systems and steel structures.

In [8] the authors presented advantages of model research e.g. possibility of increasing the precision of structure optimisation because of geometry and strength and prediction of influence of control methods of mechanisms on vibrations of steel structure and dynamic overloads. They underlined that one of the most important loads which should be considered during designing an overhead cranes were dynamic loads from hoisting mechanism. Both, the dynamic forces and energy consumption of payload lifting were defined using simulation tests taken on experimentally verified model.

The authors of [14], analyzing and forecasting of an evolution of selected crane units, paid attention to the development of transport and transhipment applications, new techniques of cranes control and improvement of safety systems..

The paper presents the continuation of research described in [6] in field of energy consumption in basic methods of payloads lifting, as well as energetic effectiveness of the developed method of dynamic overloads minimization with respect to standard methods of lifting. In addition to the basic methods of payload lifting, the solution to improve the winch operational parameters is included. The method was based on the proper structure of control system and the algorithm of accel- eration phase, using linear change of lifting speed and controller of constant power. Presented research allows to estimate advantageous parameters of acceleration phase of hoisting mechanism allowing also to minimize dynamic overloads and improvement of energetic efficiency. The presented analyses allowed to use the method both to the jerk of payloads and another methods of payload lifting. The research described below were presented on experimentally verified model of hoisting winch of overhead crane.

\section{The hoisting mechanism}

The considered hoisting mechanism of overhead crane is presented in figure 1. Mechanism was consisted of double rope system with transmission ratio 2, which was driven using geared motor fed by inverter. Mechanism ensured lifting of payload with masses up to $5 \mathrm{t}$ on $7 \mathrm{~m}$. Equipment of the stand allowed measuring of basic parameters of mechanism operation, such as speed of lifting, force in ropes and parameters of the inverter which fed drive.

The stand was used to verify the model of mechanism. The model of hoisting mechanism fed by inverter widely was described inter alia in [6] and model of inverter-motor stator system in [7]. In mechanical

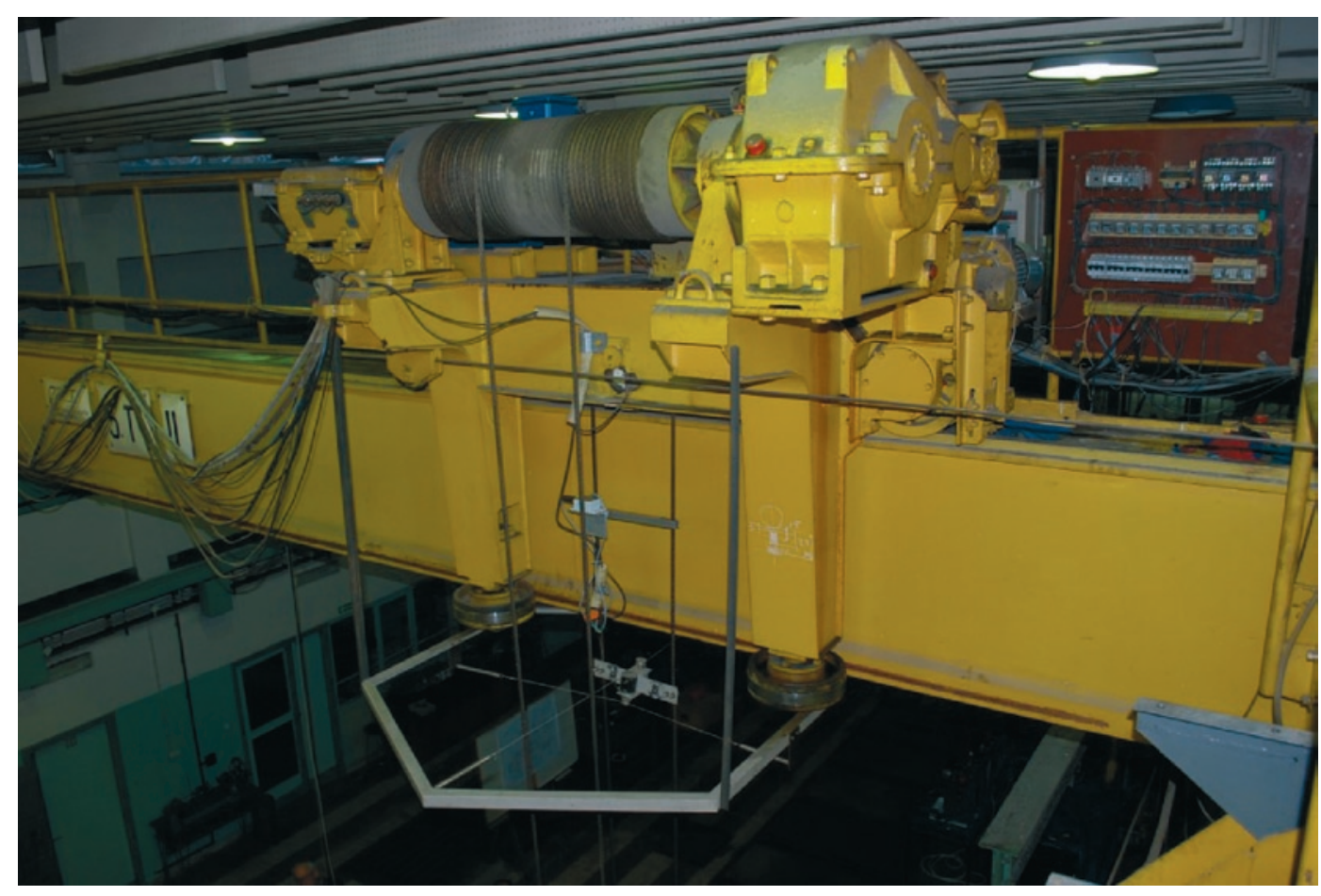

Fig. 1. The hoisting mechanism

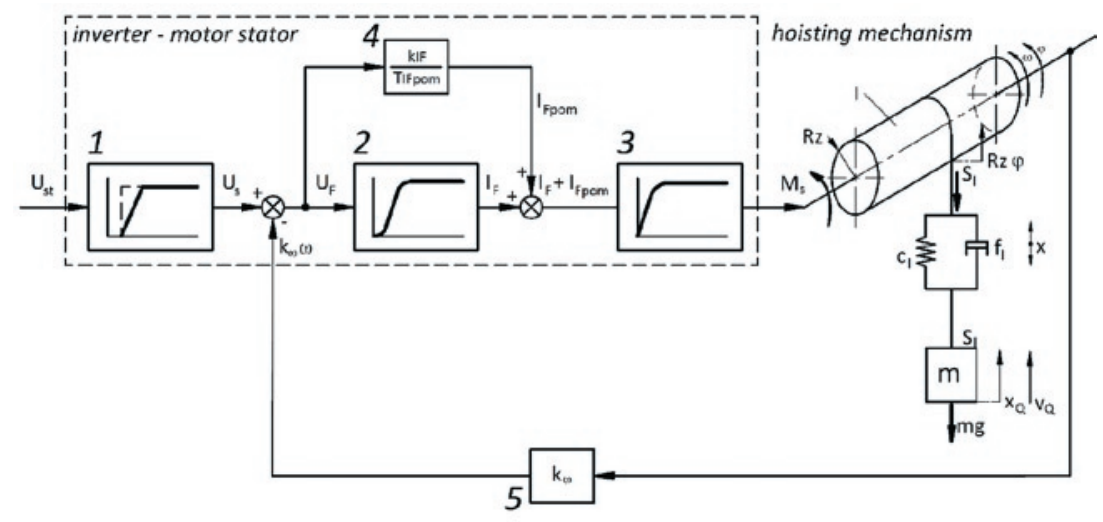

Fig. 2. The model of hoisting winch and inverter-motor stator system 
part of the winch known equations of dynamics, described inter alia in [9] were used as well as kinematic dependences of payload and elements connected with a motor. The model is presented in figure 2 .

The following parameters of elements and variables were defined:

I - moment of inertia of rotational parts of the winch reduced to the motor shaft

m - mass of lifting payload

$\mathrm{R}_{\mathrm{z}} \quad$ - effective radius of the mechanism

$\mathrm{c}_{1} \quad$ - equivalent rigidity of the rope system

$f_{1} \quad$-damping ratio of the rope system

$\mathrm{T}_{\mathrm{F} 1}, \mathrm{~T}_{\mathrm{F} 2}$ - time constants of block 2 ,

$\mathrm{k}_{\mathrm{IF}} \quad$-conversion factor of blocks 2 and 4 ,

$\mathrm{k}_{\mathrm{wzm}}$-gain factor,

$\mathrm{T}_{\text {IFpom }}$ - time constant of block 4 ,

$\mathrm{k}_{\omega} \quad$ - conversion factor of angular speed

$\mathrm{k}_{\mathrm{Ms}} \quad$-gain factor of block 3 ,

$\mathrm{T}_{\mathrm{Ms}} \quad$-time constant of block 3 .

$\mathrm{U}_{\mathrm{F}} \quad$ - control voltage signal

$\mathrm{S}_{1} \quad$-force in ropes

$\mathrm{x}_{\mathrm{Q}} \quad$ - displacement of the payload

$\varphi \quad$-angular displacement of the motor

The model described in state space notation is shown below:

mechanical part of the hoisting mechanism

$$
\begin{aligned}
& \frac{d \omega}{d t}=\frac{1}{I} \cdot M_{s}-\frac{c_{l}}{I} \cdot x-\frac{R_{z} \cdot f_{l}}{I} \cdot \omega+\frac{f_{l}}{I} \cdot v_{Q} \\
& \frac{d x}{d t}=R_{z} \cdot \omega+v_{Q} \\
& \frac{d v_{Q}}{d t}=\frac{c_{l}}{m} \cdot x-\frac{R_{z} \cdot f_{l}}{m} \cdot \omega+\frac{f_{l}}{m} \cdot v_{Q}-g
\end{aligned}
$$

a) lifting of lifted payload - pow

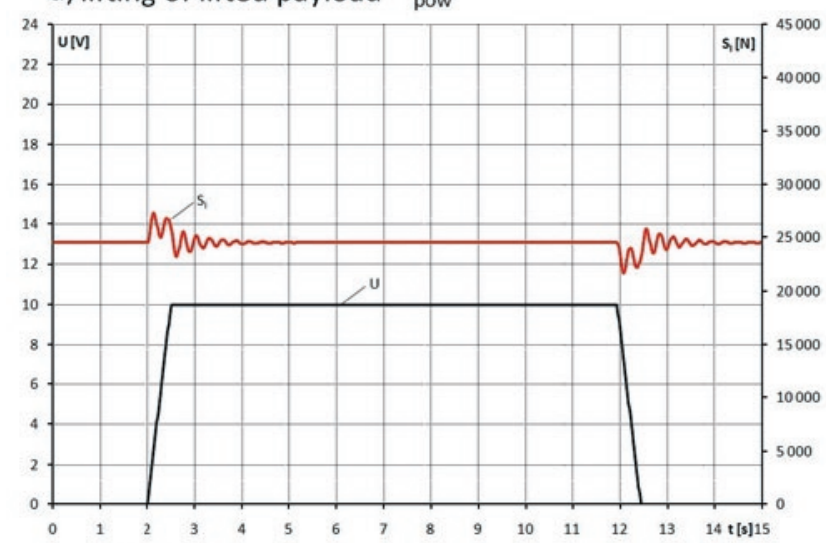

c) jerk of a payload - podr

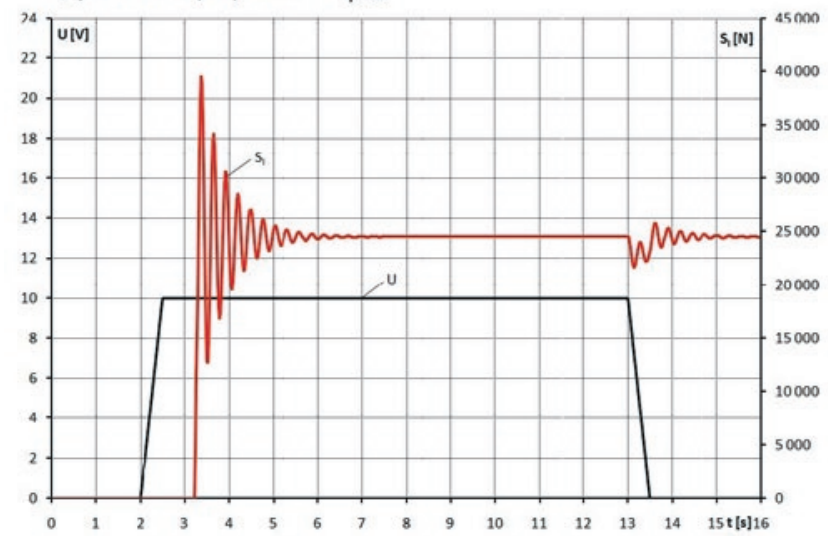

inverter - motor stator system

$$
\begin{aligned}
& \frac{d U s}{d t}=\frac{1}{T_{C}} \cdot U_{S Z} \\
& \frac{d I_{F}{ }^{\prime}}{d t}=\frac{k_{I F} \cdot k_{w z m}}{T_{F 1}^{2}} \cdot\left(U_{s}-k_{\omega} \cdot \omega\right)-\frac{T_{F 2}}{T_{F 1}^{2}} \cdot I_{F}{ }^{\prime}-\frac{1}{T_{F 1}^{2}} \cdot I_{F} \\
& \frac{d I_{F}}{d t}=I_{F}{ }^{\prime} \\
& \frac{d M_{s}}{d t}=\frac{k_{M s}}{T_{M s}} \cdot\left(I_{F}+I_{F p o m}\right)-\frac{1}{T_{M s}} \cdot M_{s} \\
& \frac{d I_{F p o m}}{d t}=\frac{k_{I F}}{T_{I F p o m}} \cdot\left(U_{s}-k_{\omega} \cdot \omega\right)
\end{aligned}
$$

The following state variables were defined:

$\mathrm{x} \quad$ - elongation of the payload ropes

$\mathrm{v}_{\mathrm{Q}} \quad$ - speed of the payload

$\omega \quad$ - angular speed of the motor.

$\mathrm{I}_{\mathrm{F}}$ - stator current,

$\mathrm{I}_{\mathrm{F}} \quad$ - auxiliary variable

$\mathrm{I}_{\text {Fpom }}$ - auxiliary stator current,

$\mathrm{M}_{\mathrm{s}}$ - torque on the motor stator,

$\mathrm{U}_{\mathrm{s}} \quad$ - control voltage signal

The input value for the model was voltage signal $U_{\text {st }}$ which was proportional to the assumed angular motor speed.

\section{Comparative studies}

Due to the conditions at the start of the lifting cycle, four cases were considered and described as follows:

b) lifting a payload from the ground - z

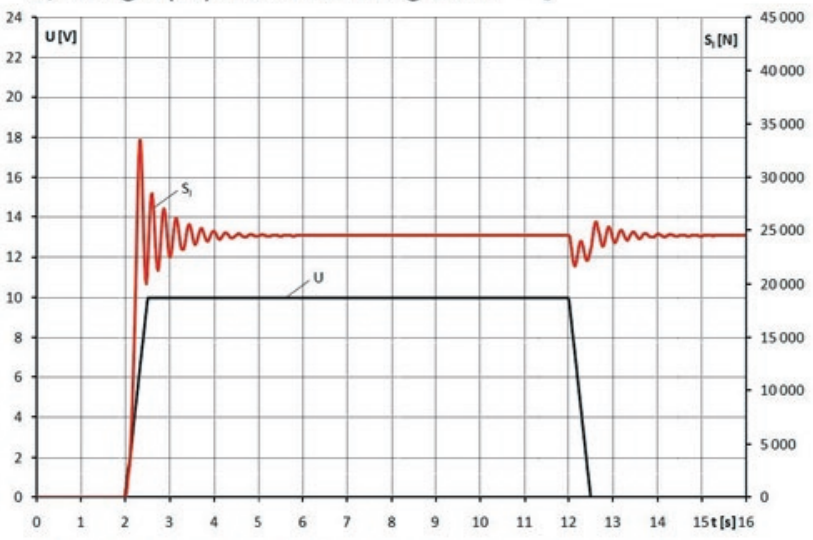

d) jerk of a payload with overloads compensation - podr_k

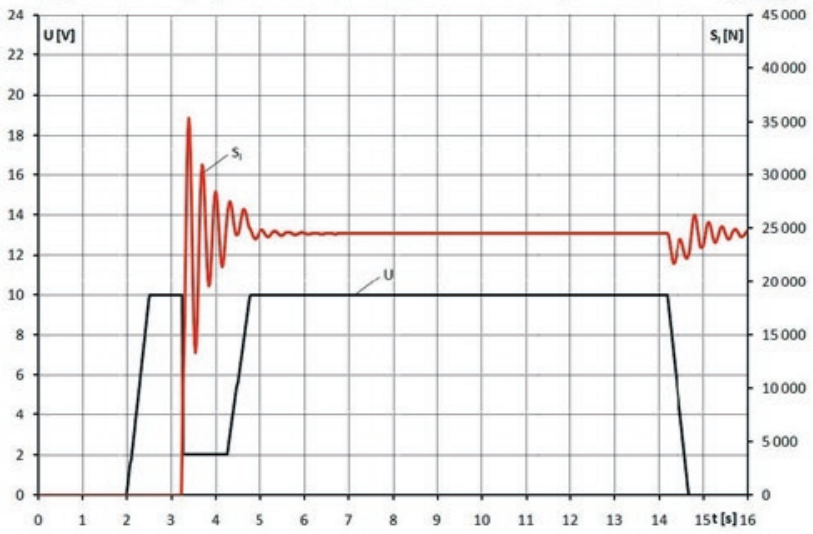

Fig. 3. The methods of payload lifting 
- lifting of lifted payload (ropes pre-strained - introduced sign - pow)

- lifting a payload from the ground (ropes not strained - introduced sign - z)

- jerk of a payload (ropes with clearance, straining began when a motor operate with steady speed - introduced sign - podr)

- In addition, the method allowing minimisation of dynamic overloads of the drive using proper shape of input function, described in [6] was considered-introduced sign - podr_k

Exemplary, taken from model tests time charts of input function and force in ropes for considered cases are presented in figure 3.

To define energy consumption of particular cycle the values connected with motor shaft were used, that are angular speed and torque between stator and rotor. These values were continuously measured (3) and calculated (4) and allowed to estimate temporary power consumption of the mechanism.

$$
\mathrm{N}=\mathrm{M}_{\mathrm{s}} \cdot \omega
$$

Due to the fact the work of the system (what means also its equivalent energy) was calculated as the integral of the temporary power due to time, it could be described as follow:

$$
\mathrm{E}=\int_{0}^{\mathrm{t}_{\mathrm{k}}} \mathrm{N} \cdot \mathrm{dt}=\int_{0}^{\mathrm{t}_{\mathrm{k}}} \mathrm{M}_{s} \cdot \omega_{s} \cdot \mathrm{dt}
$$

To define the influence of basic parameters of duty cycle such as time or method of acceleration the series of simulation tests were performed. The tests could be carried out thanks to verification tests presented inter alia in [6]. The experimental data acquisited during tests on hoisting winch were used and compared with values calculated numerically with assumption of the same input functions. Figure 4 presents time charts of motor speeds acquired from the experi- ment $\left(\omega_{\text {sreal }}\right)$ and model $\left(\omega_{\text {smod }}\right)$ forced by defined input function $\left(U_{\text {ref }}\right)$ operating in cycle of lifting the payload with mass $1130 \mathrm{~kg}$ from the ground on height equal 1,6 m. Based on experimental and model data, the total energy consumption of the cycle was calculated of about $17600 \mathrm{~J}$. A high level of compatibility between energy consumption values taken from experiment $\left(\mathrm{E}_{\text {real }}\right)$ and model $\left(\mathrm{E}_{\text {mod }}\right)$ was achieved. The maximum deviation $(\Delta \mathrm{E})$ during cycle was less than few percent (in presented case $4,29 \%$ ), while difference at the end of the cycle was less than $1 \%$. Basing on performed verification the presented model was approved for wider research on energy consumption of hoisting mechanism.

Both, a maximum overloads and a time of cycle duration depend on one of important parameters of cycle, the time of acceleration. The research of the influence of acceleration time on energy consumption was carried out when the nominal payloads masses were lifted on $5 \mathrm{~m}$ height. The times of acceleration were changing from 0 to $3 \mathrm{~s}$. The maximum forces in ropes and energy consumption of whole cycle were registered for compare purposes.

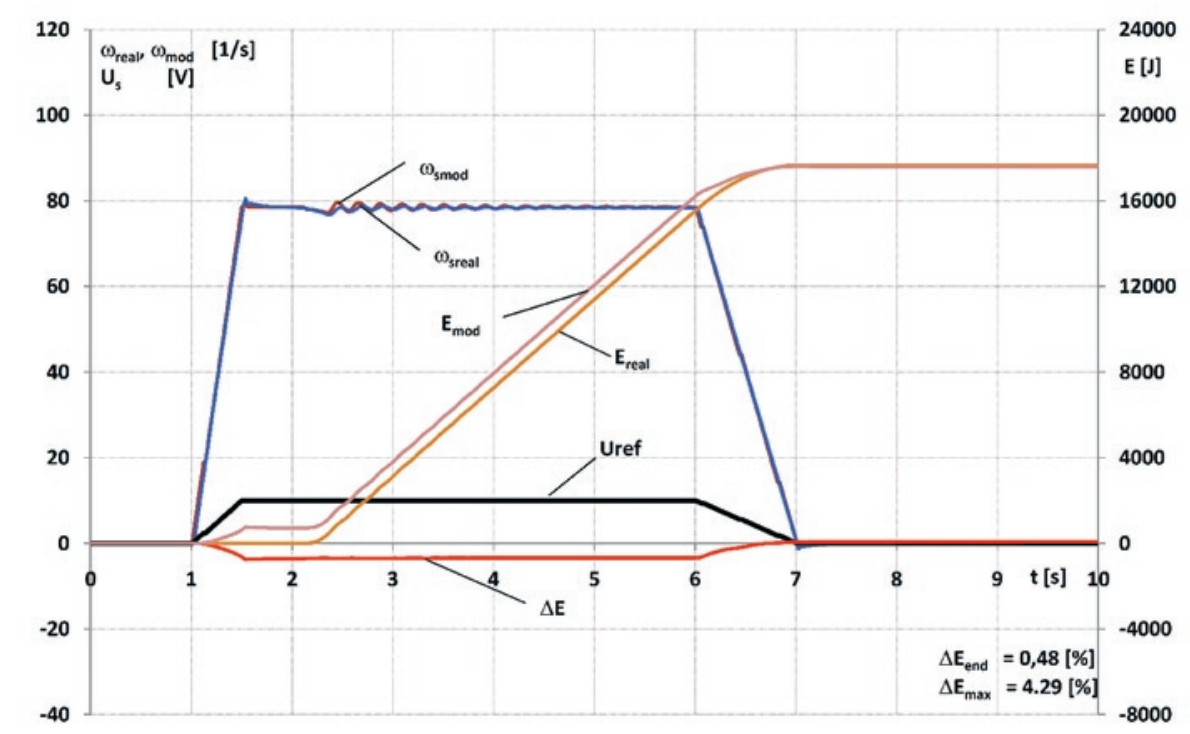

Fig. 4. Comparison of the energy of lifting cycle

Eksploatacja I Niezawodnosc - Maintenance and Reliability Vol.19, No. 4, 2017

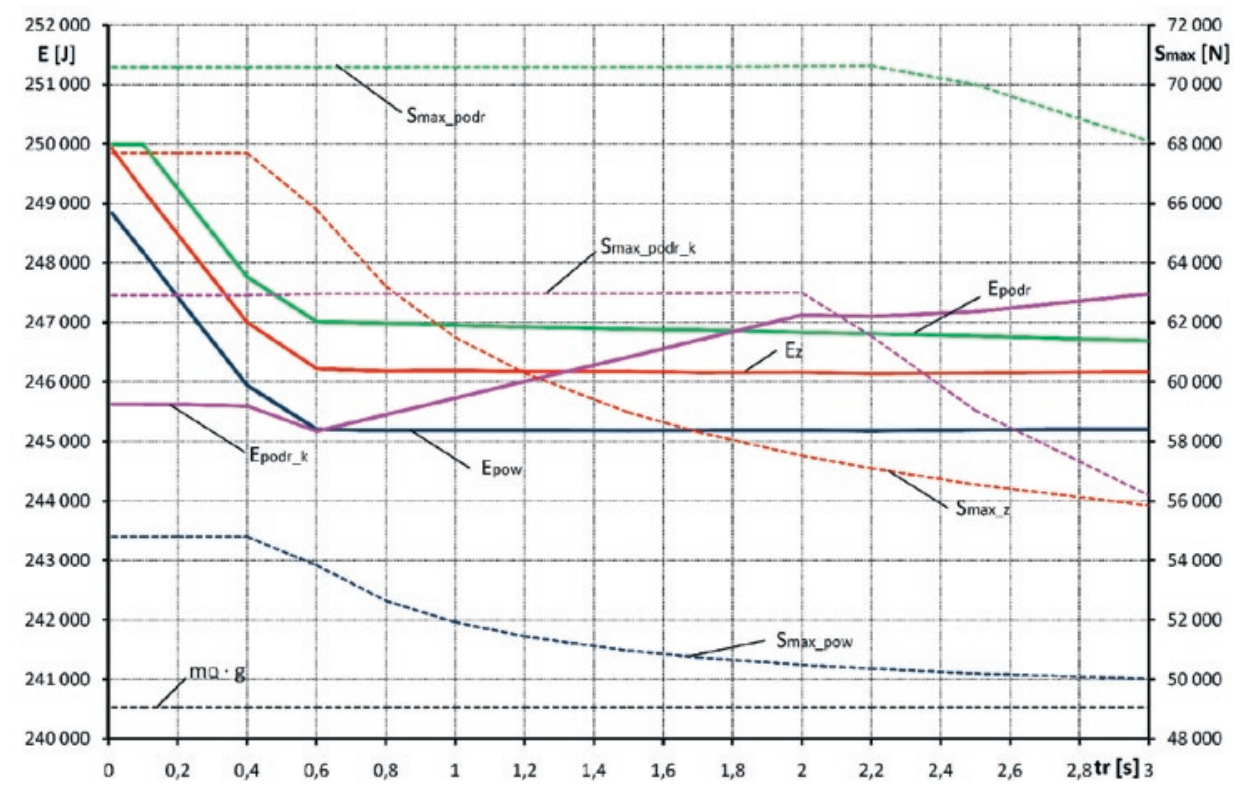

Fig. 5. Dependences of an energy consumption for the payload with mass $m_{Q}=5 \mathrm{t}$ lifted on $5 \mathrm{~m}$ height for cases of lifting from the ground, lifting of lifted payload and jerk of payload
Figure 5 presents energy consumption and maximum force in ropes for the cycle of lifting payload with mass $5000 \mathrm{~kg}$ on $5 \mathrm{~m}$ height depending on acceleration time.

The charts presented in figure 5 shows that increasing the acceleration (and braking) times independently from methods of lifting, for values above about $0,6 \mathrm{~s}$ weren't important for energy consumption of duty cycle. For the controlling method which minimized overloads, the energy consumption was smaller for shorter acceleration times and what is more, was smaller or similar with energy consumption in case of lifting of lifted payload. Simultaneously over a dozen percent decrease of the maximum force in ropes emerged.

The coefficients of overloads and energetic overloads used for comparison of effectiveness of particular methods of lifting were defined. The proper analytical dependences were given by equations: 


$$
\begin{aligned}
& \mathrm{p}=\frac{S_{\max }}{m_{Q} \cdot g} \\
& \mathrm{p}_{\mathrm{E}}=\frac{E}{m_{Q} \cdot g \cdot h}
\end{aligned}
$$

where:

p - overload

$\mathrm{p}_{\mathrm{E}} \quad$ - energetic overload

$\mathrm{S}_{\max }-$ maximum force in ropes

E - energy consumption of duty cycle of lifting

$\mathrm{m}_{\mathrm{Q}}$ - mass of a payload

$\mathrm{h} \quad$ - height of lifting

The comparisons of coefficients are presented in figures $6 \mathrm{a}$ and $6 \mathrm{~b}$.
The energy overload of lifting cycles did not exceed several hundreds of unity above one for short acceleration times and were approaching unity already from time of approximately 0,6 seconds, which was important in the context of improving the energy efficiency of the entire crane and also possibilities of energy recuperation estimation. According to overloads in ropes system, acceleration times shouldn't be less than $0,8 \mathrm{~s}$, which assures the comparable loads of structure both in case of lifting from the ground and jerk of payload with overload minimization.

Increasing acceleration times had consequences in elongation the time of the whole cycle. The dependences of the duration of whole cycle for particular methods of lifting are presented in figure 7. In case of acceleration time equal $1 \mathrm{~s}$ elongation of whole cycle in respect with duration of the cycle of lifting lifted payload was $2,1 \mathrm{~s}$ and in respect with jerk of payload was $0,96 \mathrm{~s}$.
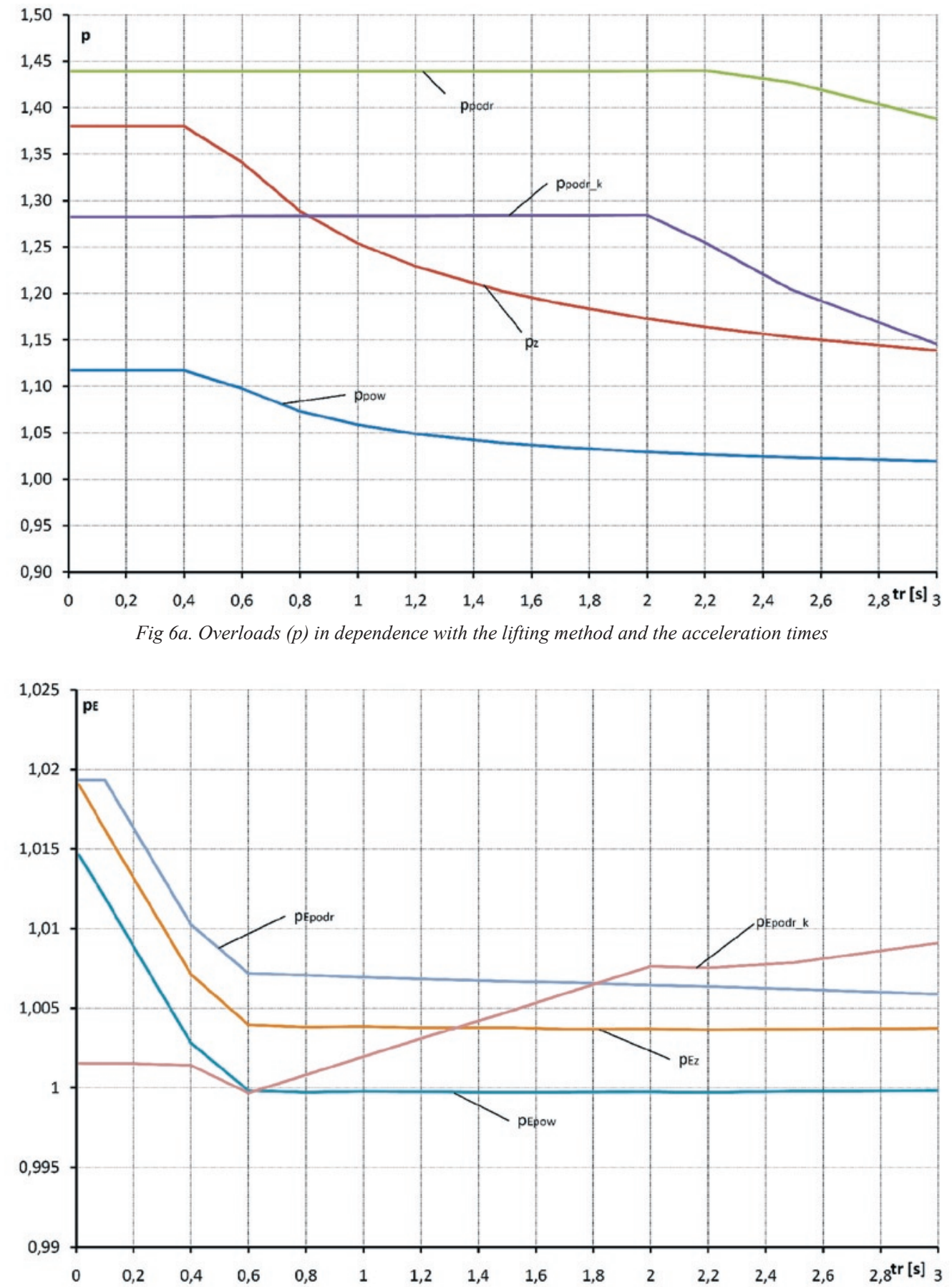

Fig $6 b$. Energetic overloads $\left(p_{E}\right)$ in dependence with the lifting method and the acceleration times 


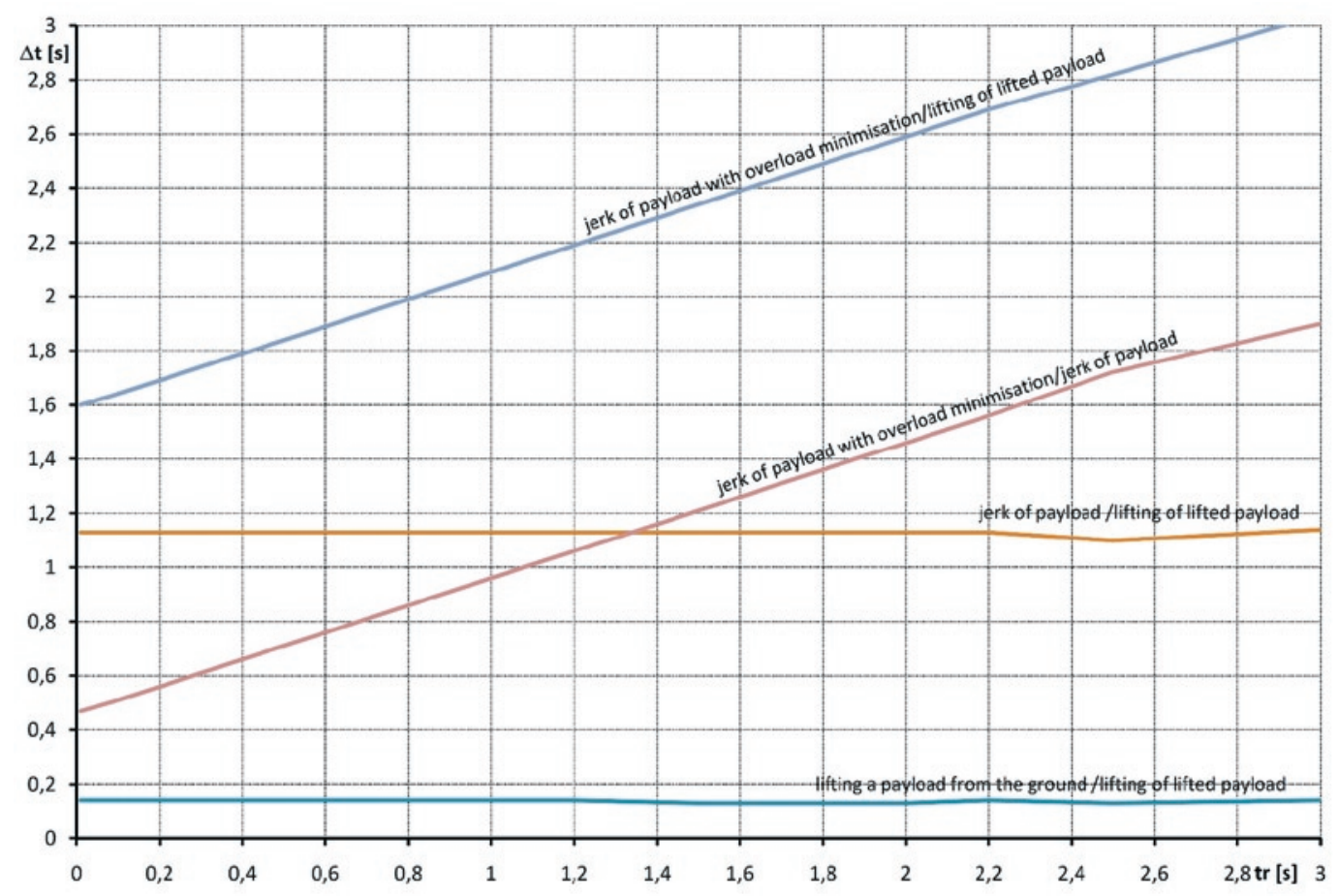

Fig 7. The elongation of cycle in dependence with the method of lifting and acceleration time of the hoisting mechanism

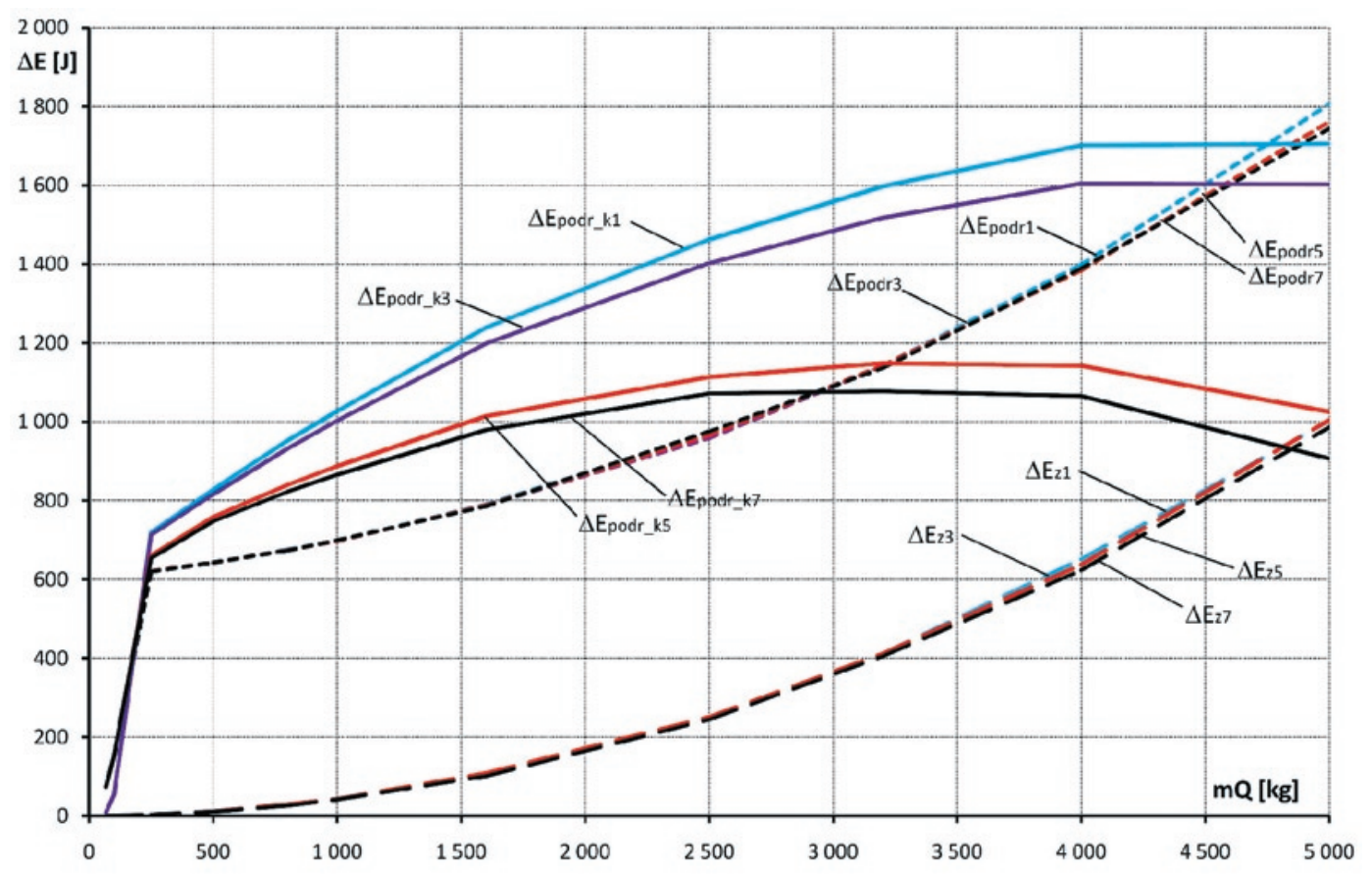

Fig 8. Coefficients of energy consumption increase in cases of lifting from the ground, jerk of a payload and jerk with overload minimization for different masses and heights of lifting

Assuming the constant value of acceleration time equal $1 \mathrm{~s}$ the research of energy consumption was conducted out for full spectrum of loads and different heights of payload lifting. The loads from empty hook to nominal load were considered. Calculations were performed for heights of payload lifting equal 1,3,5 and $7 \mathrm{~m}$.

Assuming as the reference the energy consumption during lifting of lifted payload, the coefficients of energy consumption increase $(\Delta E)$ were introduced and defined as follows:
$\Delta E_{z}=E_{z}-E_{\text {pow }}$
- for lifting from the ground
$\Delta E_{\text {podr }}=E_{\text {podr }}-E_{\text {pow }}$
- for jerk of a payload

$$
\begin{aligned}
\Delta E_{\text {podr } r_{-}}=E_{\text {podr } r_{-} k}-E_{\text {pow }}- & \text { for jerk of a payload with overload } \\
& \text { minimisation }
\end{aligned}
$$

Additional indexes 1, 3, 5 and 7 introduced in charts represented proper heights of lifting. The coefficients are presented in figure 8 .

In case of small height of lifting, the method of dynamic overloads minimization introduced increased energy consumption in full range of loads. Whereas for greater heights of lifting, for loads above half of nominal the energy consumption was smaller with respect in jerk of a payload. The energetic overload of the hoisting mechanism should be considered together with overload of driving system, especially in 


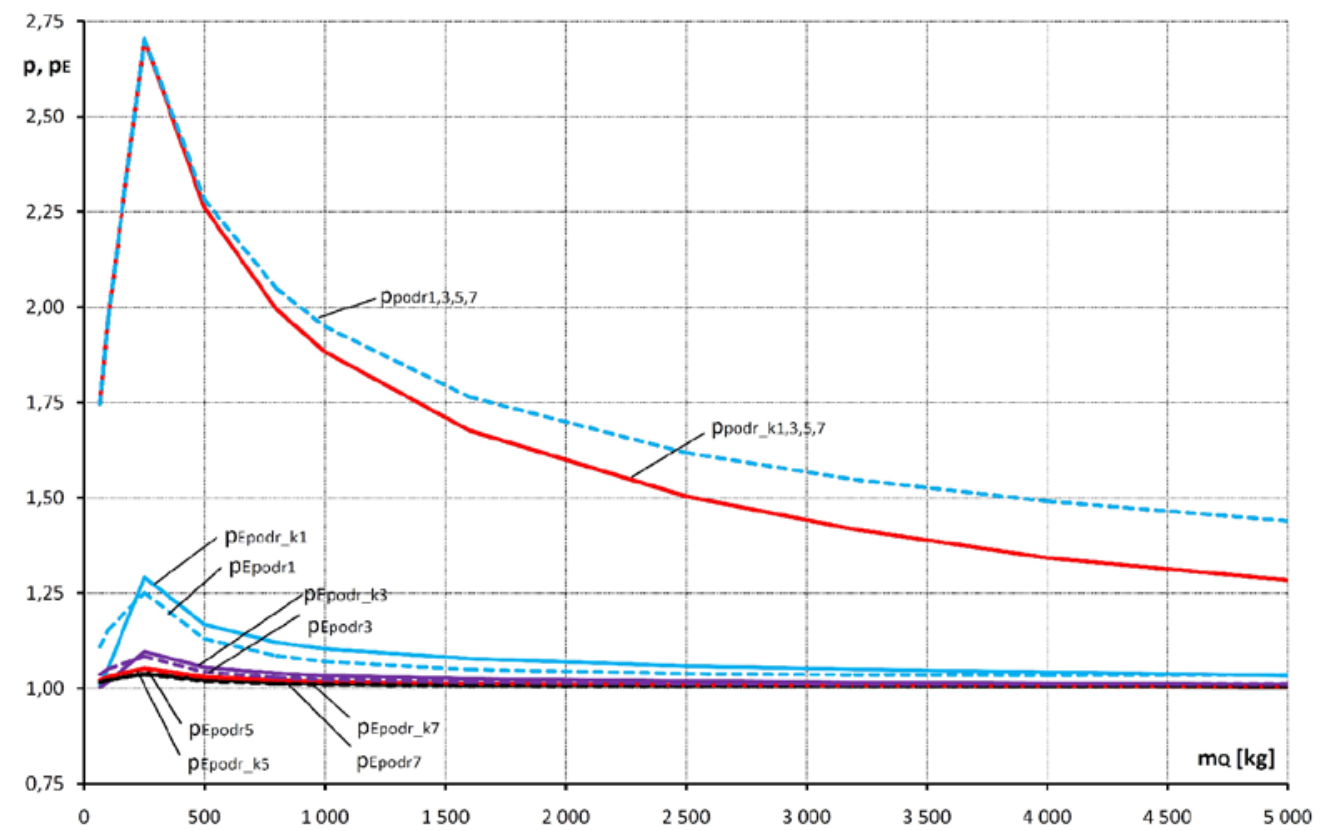

Fig. 9. The comparison of overload and energetic overloads in cases jerk of a payload and jerk with overload minimization for different masses and heights of lifting

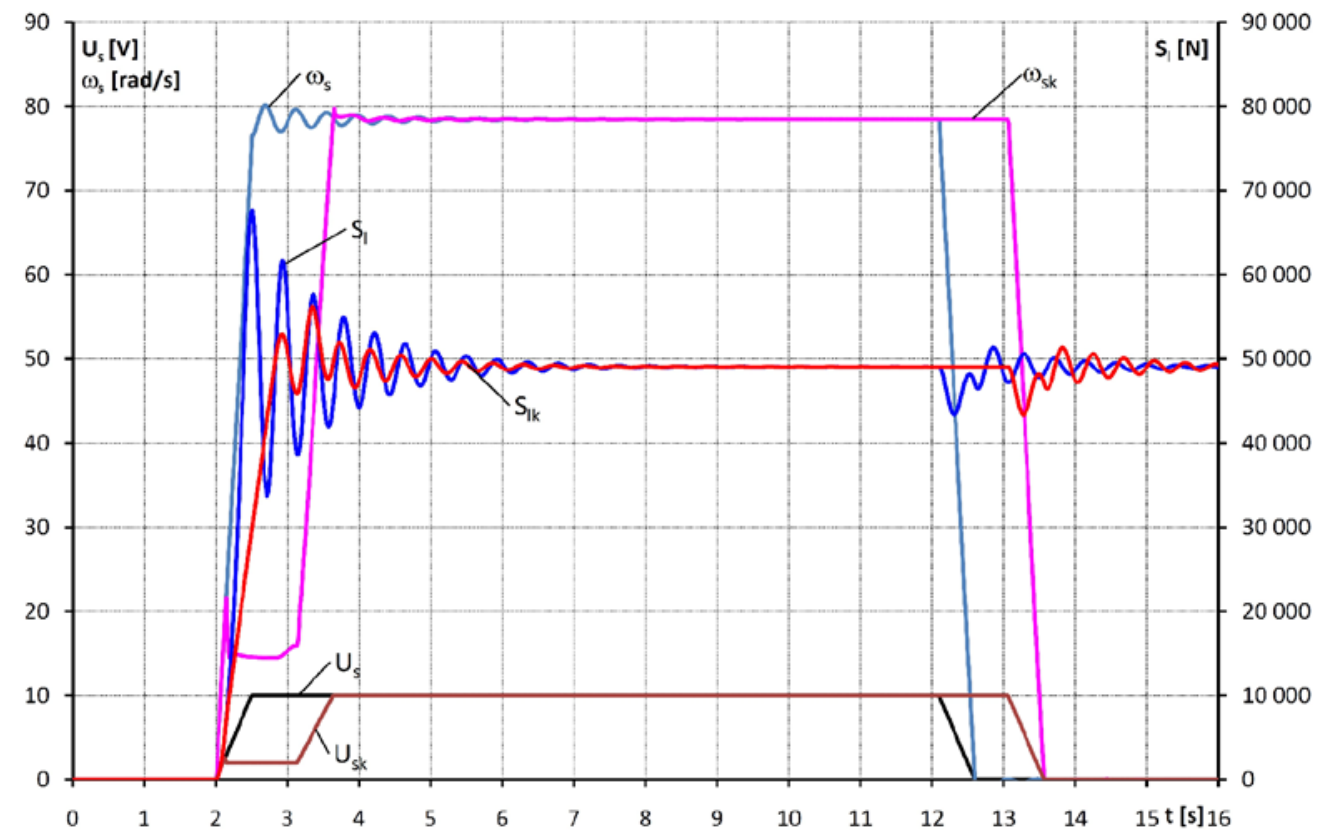

Fig. 10. The comparison of charts of input signals $\left(U_{s}\right)$, speeds of the motor $\left(\omega_{s}\right)$ and force in ropes $\left(S_{l}\right)$ in case of lifting from the ground without and with overloads minimization (index ${ }_{k}$ )

cases of jerk of a payload and jerk with overload minimisation. The comparison is shown in Figure 9.

The results showed that overloads during jerk of a payload were independent from heights of lifting, because they depended on the character of mechanism acceleration only. For small loads (up to $10 \%$ of nominal lift), overloads were independent from the method of lifting. For heavier loads, the successive reduction of overloads in cases of the payload jerk with minimization in respect to jerk of a payload were observed. Considering the energetic overloads bigger differences between particular cases were visible only for small masses.

Figure 10 presents example of usage of described method in case of lifting from the ground. The payload with mass $5000 \mathrm{~kg}$ was lifted on height $3 \mathrm{~m}$. With minimum increasing of energetic overload (from $1,008$ to 1,017$)$, minimizing of dynamic overload from $p=1.378$ to $\mathrm{pk}=1.146$ was achieved.

\section{Summary}

Performed research showed the desirability of dynamic overloads compensation not only because of the significant reduction of dynamic overloads but also because of the energy consumption of the lifting cycle.

Increased energetic overload occurred only for small masses of lifting payload and for low lifting heights. For higher lifting heights and above the half of nominal load, it was visible for used method of minimization in respect with jerk of a payload, the energetic profit.

The acceleration time which was proposed at the level of $1 \mathrm{~s}$ was beneficial both because of dynamic overloads of driving system (and steel structure) and energy consumption of cycle or time of cycle duration, independently from method of lifting. 
The method of minimization of operational loads could be used independently from method of lifting. The structure of control system did not interfere in other cases of lifting and in case of lifting of lifted payload the improvement of dynamic properties was visible.

The usage of the method gives the possibility to take into account less overloads when calculating crane carrier structures. The method decreases overloads of the structures, so in case of its usage in cranes, it helps to increase their service life as well as improves the reliability of these devices.

The preliminary works are conducted to implement the method using features which are build in inverters related to programming the acceleration phases. It allow usage the method of minimization even in case of manual control.

Visible influence of the motor speed changes during acceleration phase on driving system overloads empowers to continue research using different than presented methods of motor speed shaping, including optimization methods.

Good energetic properties of the system with minimization allows to use it in drive systems of transport devices with storage of recuperated energy e.g. during lowering.

\section{References}

1. Gąska D, Margielewicz J, Haniszewski T, Matyja T, Konieczny $Ł$, Chróst P. Numerical identification of the overhead travelling crane's dynamic factor caused by lifting the load off the ground. Journal Of Measurements In Engineering 2015; 3(1): 1-8.

2. Grygorov O V, Zaytsev Y I, Svirgun V P, Srtyzhak V V.Realization of energy-saving control modes on cranes of great load - carrying capacity. Annals of the University of Petroşani, Mechanical Engineering 2010; 12: 111-118 [3] Haniszewski T.: Hybrid analysis of vibration of the overhead travelling crane. Transport Problems (Problemy Transportu) 2014; 9(2): 89-100.

3. Haniszewski T.: Hybrid analysis of vibration of the overhead travelling crane. Transport Problems (Problemy Transportu) 2014; 9(2): 89-100.

4. Honczarenko J, Berliński A. Modelowanie energochłonności procesów transportowych w zautomatyzowanych systemach montażowych. Technologia i Automatyzacja Montażu 2011;4: 49-52.

5. Kiviluoto S, Eriksson L, Koivo H N. Modelling and control of vertical oscillation in overhead cranes. Proc. of American Control Conference 2015: 1290-1295, https://doi.org/10.1109/acc.2015.7170911.

6. Kosucki A, Malenta P. The possibilities of reducing the operational load of hoisting mechanisms in case of dynamic hoisting. Eksploatacja i Niezawodnosc - Maintenance and Reliability 2016; 18(3): 390-395, https://doi.org/10.17531/ein.2016.3.10.

7. Kosucki A. Badanie transportu ładunków przy wykorzystaniu skojarzonych ruchów mechanizmów suwnic pomostowych. Rozprawy Naukowe. Politechnika Łódzka z. 474; Zeszyty Naukowe. Politechnika Łódzka nr 1175, Łódź: 2013.

8. Margielewicz J, Haniszewski T, Gąska D, Pypno C. Badania modelowe mechanizmów podnoszenia suwnic. Komisja Transportu, Polska Akademia Nauk Oddział w Katowicach. Katowice 2013.

9. Newton I. Mathematical Principles of Natural Philosophy. NY: 1846.

10. Parise G, Honorati A. Port Cranes with Energy Balanced Drive. Proc. of AEIT Annual Conference - From Research to Industry: The Need for a More Effective Technology Transfer (AEIT) 2014: 1-5, https://doi.org/10.1109/aeit.2014.7002047.

11. Plotnikov I, Braslavsky I, Ishmatov Z, Polunin F. About Using the Frequency-Controlled Electric Drives with Supercapacitors in the Hoisting Applications. Proc. of International Siberian Conference on Control and Communications (SIBCON) 2015: 1-9, https://doi.org/10.1109/ SIBCON.2015.7147174.

12. Repo A, Montonen J, Sizonenko V, Lindh P, Pyrhönen J. Energy efficiency of hoisting motors. Proc. of International Conference on Electrical Machines (ICEM) 2014: 144-149, https://doi.org/10.1109/icelmach.2014.6960172.

13. Smoczek J, Szpytko J. Sposoby sterowania zautomatyzowanymi pomostowymi suwnicami. Prace Naukowe Politechniki Warszawskiej. Transport, 2010, z. 73: pp. 95-104.

14. Szpytko J, Chodacki J. Analiza ewolucji wybranych zespołów dźwignic, Konferencja LOGITRANS 2010, Logistyka, systemy transportowe, bezpieczeństwo w transporcie, Czasopismo: Logistyka 2010; 2.

15. Tong Yifei, Tang Zhaohui, Mei Song, Shen Guomin, Gu Feng. Research on Energy-Saving Design of Overhead Travelling Crane Camber Based on Probability Load Distribution. Mathematical Problems in Engineering 2014: 1-9.

16. Xinyi Xiao, Shiqing Lu. Study on Measurement of Energy Consumption for Cranes and Designing of Energy Saving Device. Applied Mechanics and Materials 2012; 159: 326-330, https://doi.org/10.4028/www.scientific.net/AMM.159.326.

17. Yifei T, Ruiwen Z, Wei Y, Dongbo L. Research on energy efficiency evaluation for overhead crane. Kybernetes 2016; 45 (5): 788-797, https://doi.org/10.1108/K-09-2015-0225.

18. Yifei T, Zhaohui T, Wei Y, Zhen Y. Research on energy-saving optimization design of bridge crane. Eksploatacja i Niezawodnosc Maintenance and Reliability 2013; 15 (4): 449-457.

\section{Andrzej KOSUCKI \\ Piotr MALENTA \\ Łukasz STAWIŃSKI \\ Sławomir HALUSIAK}

Lodz University of Technology, Department of Vehicles and Fundamentals of Machine Design

ul. Żeromskiego 116, 90-924 Łódź

E-mails: andrzej.kosucki@p.lodz.pl, piotr.malenta@p.lodz.pl, lukasz.stawinski@p.lodz.pl, slawomir.halusiak@p.lodz.pl 